\title{
THE INFLUENCE OF PH VALUES ON THE CRYSTALLITE SIZE OF ZnO SOLVOTHERMAL SYNTHESIS
}

\author{
Ahmadi Jaya Permana ${ }^{*}$, Dian Wulandari, Hartati, Harsasi Setyawati, \\ Mochamad Zakki Fahmi \\ Department of Chemistry Faculty of Science and Technology \\ Universitas Airlangga \\ *email: ahmadi-j-permana@fst.unair.ac.id
}

Received 11 Nopember 2017

Accepted 28 Nopember 2017

\begin{abstract}
Zinc oxide $(\mathrm{ZnO})$ is a semiconductor material that widely used in various applications due to its unique properties. Synthesis of $\mathrm{ZnO}$ by solvothermal method has been conducted with controlled $\mathrm{pH}$ values. The variations of $\mathrm{pH}$ value were 10,11 and 12 by adjusting $\mathrm{NaOH}$ content. Crystall structure of the synthesis products after heat treatment at $110 \mathrm{oC}$ and $600 \mathrm{oC}$ has been characterised by X-ray Diffratometer (XRD). Crystallite size of $\mathrm{ZnO}$ was calculated by Scherrer equation. Crystall phase of $\mathrm{ZnO}$ has been observed on all $\mathrm{pH}$ value variations at $110 \mathrm{oC}$ with 22,98-37,06 nm of crystallite size, whereas $\mathrm{ZnO}$ has been observed on all $\mathrm{pH}$ value variations at $600 \mathrm{oC}$ with $41,39-71,77 \mathrm{~nm}$ of crystallite size.
\end{abstract}

Keywords: $\mathrm{ZnO}, \mathrm{pH}$ values, crystallite size, solvothermal

\section{Introduction}

Zinc oxide $(\mathrm{ZnO})$ as semiconductor material has high stability in chemical, mechanical, photoradiation and thermal, board band gap energy and good in electrochemical and photochemical properties (Kołodziejczak-radzimska, 2014). As a semiconductor material, $\mathrm{ZnO}$ is widely used as promising materials for electronic and optoelectronic applications such as laser diodes, photoelectrodes, LEDs and gas sensors. Besides electronic application, $\mathrm{ZnO}$ is also catalyst that has lewis acid and basic for organic compounds synthesis (Kothandapani, 2016). In health and environmental application like medicine, biomedical diagnosis and therapy, water treatment, waste photodegradation, $\mathrm{ZnO}$ has antimicrobial (Król, 2017), antioxidant (Zare, 2017) and photocatalytic properties (Atchudan, 2017). According to versatile applications, $\mathrm{ZnO}$ is still attractive materials to be investigated especially in synthesis development.

Synthesis of $\mathrm{ZnO}$ by solvothermal method is an alternative method to produce single-crystalline nanostructure, controlled size and shape (Rai, 2013). In addition, solvothermal synthesis is able to produce fine and uniform nanoparticle (Sari, 2015). This method performance is influenced by reaction environment such as precursor, solvent and additives (An, 2015). Precursor, solvent and additives affect microstructures, morphology and the properties of product (Zare, 2017). Synthesis of $\mathrm{ZnO}$ by solvothermal method basicly is conducted in base environment. As an important factor, the influence of $\mathrm{pH}$ on $\mathrm{ZnO}$ synthesis has been investigated in this work.

In this research, $\mathrm{ZnO}$ has been synthesized by facile solvothermal method in various $\mathrm{pH}$ then continued with heat treatment process at $110^{\circ} \mathrm{C}$ and $600^{\circ} \mathrm{C}$. The influences of $\mathrm{pH}$ have been studied by $\mathrm{X}$ - 
ray diffraction method to study the crystall structures and crystallite size. Crystallite size average was calculated using Scherrer method.

\section{Materials and Methods}

Materials

Zinc acetate dihydrate $\left(\mathrm{Zn}\left(\mathrm{CH}_{3} \mathrm{COO}\right)_{2} .2 \mathrm{H}_{2} \mathrm{O}, \quad 99 \%\right)$, sodium hydroxide $(\mathrm{NaOH}, 98 \%)$, ethanol absolute were purchased from Sigma-Aldrich, that used without further purification.

\section{Methods}

Synthesis of $\mathrm{ZnO}$

Synthesis of $\mathrm{ZnO}$ has started by dissolving of 2 gram $\mathrm{Zn}\left(\mathrm{CH}_{3} \mathrm{COO}\right)_{2} \cdot 2 \mathrm{H}_{2} \mathrm{O}$ in $100 \mathrm{~mL}$ ethanol absolute until homogenous. The solution of $\mathrm{NaOH} 2 \mathrm{M}$ in ethanol was then added drop wise into $\mathrm{Zn}\left(\mathrm{CH}_{3} \mathrm{COO}\right)_{2}$ to adjust $\mathrm{pH}$ values to 10 , 11 and 12 while still stirred constantly and heated at $75{ }^{\circ} \mathrm{C}$ for 8 hours. The mixtures were then digest at room temperature for 24 hours. The percipitates were formed during this process then filtered and washed with demineralised water. After this, the precipitates were heated at $110^{\circ} \mathrm{C}$ and $600^{\circ} \mathrm{C}$ for 5 hours, respectively.

\section{Characterisation of $\mathrm{ZnO}$}

Phase and crystall structure was analyzed on a X-ray diffractometer (XRD) $X$ 'PERT-PRO PA using $\mathrm{CuK} \alpha$ radiation $(\lambda$ $=1,5418 \AA$ ) for $2 \theta$ values for $20-80^{\circ}$. Crystallite size was measured by X-ray peak profile analysis and calculated by Debye-Scherrer equation (Thomas, 2014).

$$
D=\frac{K \lambda}{\beta_{h k l} \operatorname{Cos} \theta}
$$

where $\mathrm{D}$ is crystallite size, $\mathrm{K}$ is Scherrer constant equal to $0,90, \lambda$ is $\mathrm{X}$-ray wavelength for $\mathrm{CuK} \alpha$ radiation equal to $1,5418 \AA, \beta_{h k l}$ is full width at half maximum (FWHM) of XRD peak and $\theta$ is diffraction angle.

\section{Results and Discussion}

Herein, white powders of $\mathrm{ZnO}$ were sucessfully synthesised by solvothermal method at all variations of $\mathrm{pH}$ value and at all temperature heat treatment. These results are following precipitation reaction of $\mathrm{Zn}(\mathrm{OH})_{2}$ then transformed to $\mathrm{ZnO}$ by heating process (Kołodziejczakradzimska, 2014)

Elimination of $\mathrm{Na}\left(\mathrm{CH}_{3} \mathrm{COO}\right)$ and $\mathrm{H}_{2} \mathrm{O}$ as side products was conducted by washing and heating process so that can produce single product of $\mathrm{ZnO}$. Figure 1 shows the difractogram of $\mathrm{ZnO}$ with similar XRD peaks pattern of all $\mathrm{pH}$ variation at $110^{\circ} \mathrm{C}$. The XRD peaks pattern are indexed to JCPDS 36-1451 that confirm the hexagonal wurtzite phase of $\mathrm{ZnO}$. There are no other crystalline phase detected that mean this synthesis method produce single crystalline phase of $\mathrm{ZnO}$. Besides all $\mathrm{pH}$ variation show similar pattern, the XRD peak intensity ratio are quite similar at all $\mathrm{pH}$ variations

Single cristallinity of hexagonal wurtzite phase of $\mathrm{ZnO}$ showed on Figure 2. Peak intensity of XRD increased at all $\mathrm{pH}$ value along the increasing of temperature from $110^{\circ} \mathrm{C}$ to $600^{\circ} \mathrm{C}$. Similar results with heat treatment at $110^{\circ} \mathrm{C}, \mathrm{XRD}$ peak intensity ratio are quite similar at all $\mathrm{pH}$ value that indicates similar shape and morphology formation (Jaimeewong, 2016)

$$
\begin{gathered}
\mathrm{Zn}\left(\mathrm{CH}_{3} \mathrm{COO}\right)_{2} \quad+\mathrm{NaOH} \rightarrow \mathrm{Zn}(\mathrm{OH})_{2}+2 \mathrm{Na}\left(\mathrm{CH}_{3} \mathrm{COO}\right) \\
\mathrm{Zn}(\mathrm{OH})_{2} \underset{\Delta}{\rightarrow} \mathrm{ZnO}+\mathrm{H}_{2} \mathrm{O}
\end{gathered}
$$




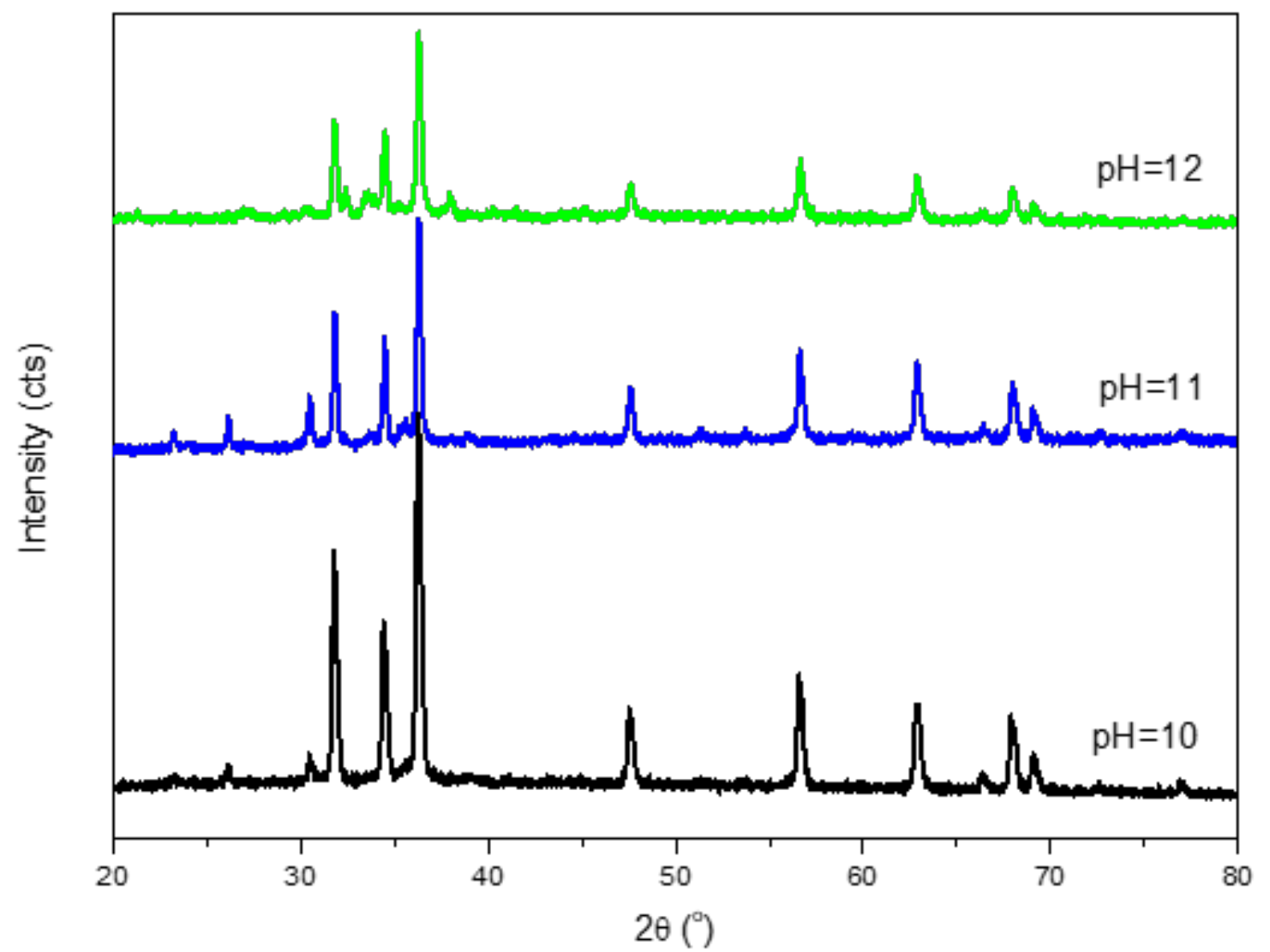

Figure 1. XRD difractograms of $\mathrm{ZnO}$ products of different $\mathrm{pH}$ variation at $110^{\circ} \mathrm{C}$

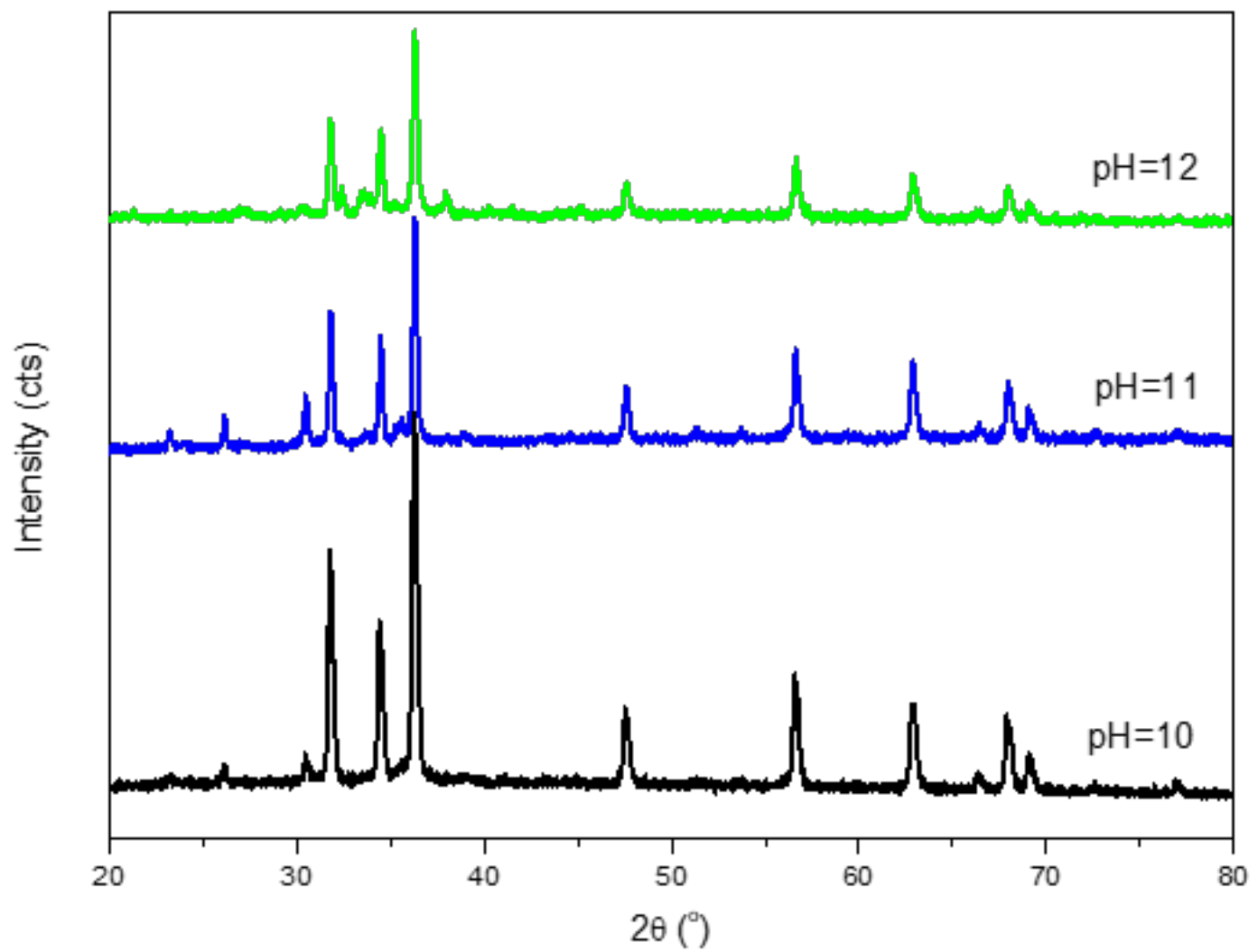

Figure 2. $\mathrm{XRD}$ difractograms of $\mathrm{ZnO}$ products of different $\mathrm{pH}$ variation at $600^{\circ} \mathrm{C}$ 
Table 1. Crystallite size average of $\mathrm{ZnO}$

\begin{tabular}{cccc}
\hline Temperature $\left({ }^{\mathbf{0}} \mathbf{C}\right)$ & \multicolumn{3}{c}{ Crystallite Size Average $(\mathbf{n m})$} \\
& $\mathbf{p H}=\mathbf{1 0}$ & $\mathbf{p H}=\mathbf{1 1}$ & $\mathbf{p H}=\mathbf{1 2}$ \\
\hline $\mathbf{1 1 0}$ & 22,98 & 37,06 & 26,12 \\
$\mathbf{6 0 0}$ & 71,77 & 54,23 & 41,39 \\
\hline
\end{tabular}

The influence of $\mathrm{pH}$ value variations to crystallite size of $\mathrm{ZnO}$ can be oberved on Table 1 . At $110^{\circ} \mathrm{C}$, there are no corelation results about the influence of $\mathrm{pH}$ value to $\mathrm{ZnO}$ crystallite size due to the diffrence of products transformation to $\mathrm{ZnO}$. The product formation before heat treatment at $\mathrm{pH} 10$ are dominantly $\mathrm{Zn}(\mathrm{OH})_{2}$, product at $\mathrm{pH} \quad 11$ are dominantly $\mathrm{Zn}(\mathrm{OH})_{2}$ and $\mathrm{Zn}(\mathrm{OH})_{3}{ }^{-}$and product at $\mathrm{pH}=12$ are dominantly $\mathrm{Zn}(\mathrm{OH})_{3}{ }^{-}$(Pandit, 2017). The increased of heat temperature increase the crystallite size of $\mathrm{ZnO}$ because the inccreased of aggregation process (Jaimeewong, 2016). The influence of $\mathrm{pH}$ value observed the decreased of the crystallite size from 10 to 12 . The function of $\mathrm{NaOH}$ on solvothermal method as mineraliser and catalyst (An, 2015) can be

\section{References}

An, A., Marin, M., Crnjak, Z., and Majda, Ž. (2015). Basic zinc carbonate as a precursor in the solvothermal synthesis of nano-zinc oxide, 86,347 353.

http://doi.org/10.1016/j.matdes.2015. 07.087

Atchudan, R., Nesakumar, T., Immanuel, J., Perumal, S., Shanmugam, M., and Rok, Y. (2017). Journal of Photochemistry and Photobiology A : Chemistry Direct solvothermal synthesis of zinc oxide nanoparticle decorated graphene oxide nanocomposite for ef fi cient photodegradation of. "Journal of Photochemistry and Photobiology, A: Chemistry," 337, 100-111. http://doi.org/10.1016/j.jphotochem.2 017.01 .021 the reason about the decreased of the crystallite size.

\section{Conclusions}

To conclude, $\mathrm{ZnO}$ have successfully been synthesized by solvothermal method. $\mathrm{ZnO}$ were formed in all of $\mathrm{pH}$ values variation at both $110^{\circ} \mathrm{C}$ and $600^{\circ} \mathrm{C}$ temperature of heat treatment. Synthesis of $\mathrm{ZnO}$ at $\mathrm{pH}=10$ at $600^{\circ} \mathrm{C}$ resulted highest XRD peak intensity and greatest crystallite average size to $71,77 \mathrm{~nm}$.

\section{Acknowledgements}

We thank to Faculty of Science and Technology for the financial support by Hibah Dosen Muda Dana RKAT Fakultas Sains dan Teknologi Universitas Airlangga Tahun 2017 Nomor SP POPA 628/UN3.6/KU/2016.

Jaimeewong, P., Promsawat, M., Jiansirisomboon, S., and Watcharapasorn, A. (2016). Surface and Coatings Technology In fl uence of $\mathrm{pH}$ values on the surface and properties of BCZT nanopowders synthesized via sol-gel autocombustion method. Surface and Coatings Technology, 306(3), 16-20. http://doi.org/10.1016/j.surfcoat.2016 .03 .091

Kołodziejczak-radzimska, A., and Jesionowski, T. (2014). Zinc OxideFrom Synthesis to Application: A Review, 2833-2881. http://doi.org/10.3390/ma7042833 
Kothandapani, J., Ganesan, A., and Kumar, G. (2016). Zinc oxide surface : a versatile nanoplatform for solvent-free synthesis of diverse isatin derivatives. Tetrahedron Letters, 57(31), 3472-3475. http://doi.org/10.1016/j.tetlet.2016.06 .094

Król, A., Pomastowski, P., Ra, K., and Buszewski, B. (2017). Zinc oxide nanoparticles: Synthesis antiseptic activity and toxicity mechanism. http://doi.org/10.1016/j.cis.2017.07.0 33

Pandit, A. B., and Badnore, A. (2017). Effect of $\mathrm{pH}$ on sonication assisted synthesis of $\mathrm{ZnO}$ nanostructures: Process details Corresponding author. Chemical Engineering and Processing: Process Intensification. http://doi.org/10.1016/j.cep.2017.09. 013

Rai, P., Kwak, W., and Yu, Y. (2013). Solvothermal Synthesis of $\mathrm{ZnO}$ Nanostructures and Their Morphology-Dependent Gas-Sensing Properties.
Sari, A., Stefani, G., and Dra, G. (2015). Solvothermal synthesis of zinc oxide microspheres, 652, 91-99. http://doi.org/10.1016/j.jallcom.2015. 08.200

Thomas, P. B. S. (2014). Estimation of lattice strain in $\mathrm{ZnO}$ nanoparticles : $\mathrm{X}$ ray peak profile analysis, 123-134. http://doi.org/10.1007/s40094-0140141-9

Zare, M., Namratha, K., Byrappa, K., Surendra, D. M., Yallappa, S., and Hungund, B. (2017). Surfactant assisted solvothermal synthesis of $\mathrm{ZnO}$ nanoparticles and study of their antimicrobial and antioxidant properties. Journal of Materials Science and Technology. http://doi.org/10.1016/j.jmst.2017.09. 014 